\title{
THE CONSTITUTIONAL PREMISES OF SUBNATIONAL SELF-GOVERNMENT IN NEW DEMOCRACIES
}

PAUL BLOKKER ${ }^{1}$

\begin{abstract}
The paper discusses the significance and role of subnational democracy in the context of new European democracies in flux. In a context of fragile democratic traditions, the displacement of national sovereignty, and increasing civic adverseness to national politics, local forms of representative and direct democracy might - in advantageous circumstances - help to re-attach citizens to the democratic process. What is more, enhanced civic input into local and regional policy-making may enhance local capacities and strengthen forms of local cooperation. Subnational democracy might therefore work as a partial antidote to problems of European democracies, and in particular in the post-communist context. Local forms of democratic interaction have particular significance in the new democracies in that legacies of paternalism, hyper-centralized politics, socialist legality, and deeply engrained distrust towards politics tend to discourage democratic participation. Democracy on the local and regional levels is of a particularly intricate nature in that it is dependent on the way it is institutionalized and constitutionalized, and thus on legal guarantees of autonomy as well as on distinct values of self-government as communicated by constitutions. The paper will discuss the promises and problems of subnational democracy, and will subsequently briefly explore the constitutional premises of subnational selfgovernment in the Czech Republic, Hungary, and Poland. The emerging picture shows both an increasing role for subnational self-government and significant hurdles to more widespread democracy on the local level.
\end{abstract}

Keywords Constitutions, East-Central Europe, decentralization, subnational democracy

1 Paul Blokker, Ph.D. is post-doctoral fellow at the Department of Sociology, University of Trento; e-mail:paulus.blokker@soc.unitn.it 
The paper discusses the significance and role of subnational democracy in the context of new European democracies in flux. In a context of fragile democratic traditions, the displacement of national sovereignty, and increasing civic adverseness to national politics, local forms of representative and direct democracy might - in advantageous circumstances - help to re-attach citizens to the democratic process. What is more, enhanced civic input into the local and regional policy-making may further local capacities and strengthen forms of local cooperation. Subnational democracy might therefore work as a partial antidote to efficiency (output legitimation) and legitimacy (input legitimation) problems of European democracies. In this, local forms of democratic interaction have particular significance in the new democracies in that legacies of paternalism, centralized politics, socialist legality, and a generalized distrust towards politics have tended to discourage the democratic participation. Democracy on the local and regional levels is of a particularly intricate nature in that it is dependent on the way political government is institutionalized and constitutionalized, and thus on legal guarantees of autonomy as well as on distinct values of self-government as communicated by constitutions.

The paper starts with a discussion of the significance of decentralization, subnational self-government, as well as civic participation in the European context, and the argument will be made that firm constitutional foundations are one necessary condition for viable subnational self-government. In a second step, the constitutional orders of the Czech Republic, Hungary, and Poland will be briefly reviewed, focusing on their definitions of state and entrenchment of subnational forms of government and democracy. In the conclusion, it will be argued that significant forms of decentralized government and democracy have emerged in all three countries, but also that reforms have not been of an unambiguous kind and that important tensions and problems persist as a result.

\section{THE SIGNIFICANCE OF SUBNATIONAL DEMOCRACY IN TIMES OF DEMOCRATIC CHANGE}

In the post-Second World War period, democracy in Europe referred predominantly to representative democracy, firmly situated and organized on the national level. Indeed, democratic theory was often explicitly against forms of decentralized, and in particular direct or participatory democracy. This is particularly evident in the widely influential statement on democracy as a competitive elite affaire by Joseph Schumpeter (Loughlin, Hendriks, and Lindstrom 2010: 2). 
With the crisis of Keynesianism and the advent of neo-liberal anti-statism and evermore influential globalization, however, the relationship between the national state and democracy has become a growing object for discussion. It is now increasingly argued that local or subnational democracy matters, and can in effect play an important role in revitalizing and reinvigorating democratic systems. However, while in the neo-liberal dictionary that became dominant in the 1980s, local democracy would mostly relate to diminishing the influence of the centralized state and enhancing the role of civil society, notably economic agents, from the 1990s onwards, it was now also increasingly realized 'that political decentralization and local autonomy were important elements of democracy itself' (Loughlin, Hendriks, and Lindstrom 2010: 5). Strengthening local government and local democracy could thus for a number of reasons be seen as potentially enhancing the quality of a democratic state, for instance, resulting from the proximity of local politics to the citizens, the higher accessibility of local politics to participation, in particular if in the form of direct and deliberative forms of democracy (Schiller 2011), and the shorter reaction time of local government to policy issues (Bailey and Elliott 2009: 436).

In political-theoretical terms, the local democratic narrative that emphasizes the democratic surplus value of local democracy can be understood as a kind of amalgam of republican political thought (emphasizing civic virtue, public autonomy, and civic engagement), communitarianism (politics close to the citizens), as well as ideas of deliberative democracy (politics as based on inclusion, deliberation, and consensus-building). It seems undeniable that at least in superficial terms this narrative has become increasingly important in addressing problems of policy-making in European democracies. One clear sign of this is the emphasis on regionalization in European integration and the adoption of the European Charter of Local Self-Government (1985).

The increased attention for forms of decentralization, public participation, and forms of participatory and direct democracy comes, however, exactly in a period in which constitutional democracy is increasingly subject to great tensions and transformations. First, there is - in Europe - the evident shift in political and constitutional weight towards the European level. In other words, the overlap and concentration of a jurisdiction, a territory, and a people is increasingly less evident as important decisions and politics regarding a variety of political communities are taken outside of those communities. Second, in a related way, there is the increasing complexity and arcane streak that matters of governance and democratic politics display. Third, there is the increasing civic disattachment - in both East and West - vis-à-vis representative democratic politics. National political elites and institutions are profoundly lacking in civic trust and legitimacy. 


\section{SUBNATIONAL DEMOCRACY AS ANTIDOTE?}

In normative terms, it can be argued that local self-government can provide a partial anti-dote to democratic deficits and disengagement in a number of ways. First, the strengthening of local democracy will make constitutional democracies more pluralistic, in that political power becomes divided and diffused on the vertical level, which helps to avoid, on the one hand, the political hegemony of central governmental institutions (a salient objective in former totalitarian societies), and, on the other, might help recover some of the lost grasp of democratic sovereignty on politics. Second, local selfgovernment makes it easier for citizens to participate in democratic politics and governance in a meaningful way than it would be when politics is completely centralized. Third, and as is probably most famously argued by J.S. Mill, local possibilities for democratic participation might help to foster sentiments of public autonomy among the citizenry:

It is necessary, then, that, in addition to the national representation, there should be municipal and provisional representations; and the two questions which remain to be resolved are, how the local representative bodies should be constituted, and what should be the extent of their functions. In considering these questions, two points require an equal degree of our attention: how the local business itself can be best done, and how its transaction can be made most instrumental to the nourishment of public spirit and the development of intelligence (Mill 2004: 512).

Fourth, local self-government might in some instances also be a more effective type of government, in that it is more likely to have a capacity of responsiveness, in terms of responding to local problems according to local views.

Local self-government is then by many seen as a kind of anti-dote to at least some of the problems of modern democratic regimes, not least that of civic engagement, but also regarding the increasing complexity of issues of governance. It can, however, be argued that local government and local democracy are no obvious panacea to democratic and governance problems. Stephen Bailey and Mark Elliott have for instance recently argued that local government is only likely to deliver the goods when a 'virtuous circle' is created, that is, a situation in which 'the obvious importance and responsiveness of local government incentivizes the participation of individuals in local politics and elections' (Bailey and Elliott 2009: 436). In other words, '[a]tempts to strengthen local democracy must, on this view, go hand- 
in-hand with attempts to strengthen local government'. In reality, however, many central governments have failed to induce such a virtuous circle "within which strong local democracy and powerful institutions of local government enjoy a symbiotic, mutually constructive relationship'. Rather, governments have tended to contribute to a 'vicious circle' in which 'extensive central control, the consequent limitations to local power and autonomy and the disengagement of individuals and communities are factors that are mutually reinforcing' (Bailey and Elliott 2009: 437).

\section{SIGNIFICANCE OF SUBNATIONAL DEMOCRACY IN THE NEW DEMOCRACIES}

The importance of local government and democracy in the post-totalitarian context of Central and Eastern Europe is self-evident. The highly centralized systems of communism - indeed coined "democratic centralism" in Leninist systems - did not allow for any significant participation or voice by either stakeholders or the citizenry at large. What is more, the far-going centralization of communist political systems meant that no form of subnational autonomy or territorial self-government was allowed for. Not by coincidence the discourses of protest of many dissidents movements in the region contained a strong dimension of civic participation, decentralization, and local selfgovernment (see Renwick 2006; Blokker 2011).

The past communist systems were detrimental to any idea of formal subnational self-government ${ }^{2}$ in at least two ways. First, subnational forms of government were always strictly controlled by the central state, and therefore merely consisted in institutions for the execution of centrally imposed policies, lacking any kind of space for autonomous action in the interest of local populations. Second, not only did democratic centralism mean that no democratic channels were available for civic participation, but also any kind of political pluralism within the communist political institutions was reduced as far as possible, in that the state was subjected to the communist party with its homogenous program and ideological principles, while alternative voices were stifled under the banner of "enemies of the people".

In addition, the "socialist legality" that underpinned the political structure of communist regimes was based upon "paper constitutions" that did have very little to do with the rule-of-law and were rather a fiction or form of symbolism

2 In the informal reality of "socialist realism", there were different ways of circumventing central control. 
(in a pejorative sense) that displayed a huge discrepancy with the arbitrary nature of political-legal reality (cf. Skapska 2011). Rather than contributing to social integration and the constitution of political communities, the "paper" communist constitutions helped to enhance existing traditions of "us and them", or, in other words, a deep distrust of society against the ruling elites.

The 1970s and 80s, as well as the early 1990s saw a fierce backlash against the centralism and political party-monism that had been imposed with communism. In particular in the early 1990s, radical steps were undertaken to undo the hypercentralization of the past. However, such reforms tended to run out of steam fairly quickly, not least due to increased disagreement about the exact nature of reforms, but the subnational reform process has continued in a more gradual manner in most societies in the post-communist region.

\section{THE CONSTITUTIONALIZATION OF SUBNATIONAL DEMOCRACY}

This brings us to the process of decentralization, and of institutionalization and constitutionalization of subnational democracy in the two decades of post-communist transformation. An important question to ask is whether the transformation process has significantly contributed to the consolidation of vital constitutional democracies, which involve robust dimensions of pluralized and decentralized politics and promote active citizenship, or whether constitutional democracy has largely remained a fiction (cf. Skapska 2011: 9)? Any attempt at answering this question will need to take into account the foundations of these new democracies, and whether these are conducive or not to civic democracy. Indeed, with regard to subnational self-government, the assessment of a "virtuous circle" of local government and democracy as identified by Bailey and Elliott above needs a holistic view of the place of local government and democracy in the wider democratic-constitutional order. This means that the problems related to stimulating a virtuous form of local democracy 'can be fully faced up to only if important questions about the legal and constitutional role of local government are squarely addressed' (Bailey and Elliott 2009: 437). In other words, the foundations of decentralization and devolution are significant and need to be explicit and clear-cut if a virtuous type of local government and democracy is to be expected to emerge.

The rest of the paper will then engage in primis with the constitutional premises of subnational-self government and in particular of local democracy, in terms of the constitutionalization of subnational government (municipal, county, regional) and of forms of representative and direct democracy. The 
constitutional dimension can itself be broken down into two meta-dimensions - an instrumental and a symbolic one. These meta-dimensions can themselves be differentiated into a range of functional dimensions of constitutions (see Blokker 2010). A primary functional dimension regarding the instrumental rationality of constitutions is that of an instrumental, power-ordering and limiting dimension. Here, the function of the constitution is to arrange for the mapping and division of political power, in terms of institutional prerogatives and competences, and forms of checks and balances. Regarding the local level, this largely negative function (in terms of the limitation of political power) includes the level of decentralization in terms of division of competences and oversight between central, regional, and local levels, as well as fiscal autonomy. A further dimension is the formal-participatory dimension which arranges for the possibilities of formal-procedural participation by citizens in terms of representative institutions on the local and regional levels.

With regard to the symbolic or sociological rationality of constitutions (cf. Skapska 2011), at least two further dimensions are relevant for local government and democracy. The first is the normative dimension, which relates to the axiological nature or constitutional morality that constitutions express. Of importance for local government and democracy are here the constitutional inclusion of notions such as subsidiarity, the right to local selfgovernment and autonomy as foundational values, and the value of direct and indirect civic participation. The second is the substantive-participatory dimension, which relates to effective forms of civic participation in democratic politics in terms of direct and deliberative democracy.

\section{CONSTITUTIONALIZATION OF SUBNATIONAL DEMOCRACY IN THE NEW DEMOCRACIES ${ }^{3}$}

Ideas of local self-government and local (representative and direct) democracy have had a visible impact on the post-1989 constitutional and legal orders of the Czech Republic, Hungary, and Poland, and while the initial radicalism of changes of the early 1990s did not continue in later years of transformation, the three democracies analyzed here all display significant levels of decentralization. At the same time, though, the constitutional and legal developments demonstrate a variegated impact of ideas of local democracy and direct forms of democracy. Below I will briefly trace the constitutional trajectories of the three new democracies with regard to the

3 This part is partially based on Blokker 2011. 
overall definition of the state, forms and definitions of decentralization, and forms and definitions of subnational democracy.

\section{The Czech Republic}

The constitutional state in the Czech Republic can best be defined as a predominantly centralized, unitary state, based on a parliamentary-democratic system (cf. Illner 2010). However, this does not mean that the local and regional levels of government are not important, nor that more direct forms of democracy or active citizenship are inexistent or not part of the constitutional order. This becomes, for instance, already clear from the symbolic-substantive reference to civil society in the preamble of the 1992 Constitution: "a free and democratic state based on the respect for human rights and the principles of civic society". However, some have argued that while some forms of decentralization and self-government are part and parcel of the Czech system, its main logic is that of "state administration" (Bryson 2008).

Below, I will briefly trace the constitutional contours of both local selfgovernment and local democracy as these have emerged in the 1990-2010 period. It will become clear that there is a tensional relation both between state-centralistic and decentralized views of the Czech polity as well as between representative and direct views of democracy.

\section{Constitutional Design of Local Government}

The Czech state as it emerges from the 1992 Constitution is a sovereign, unitary and democratic state: "The Czech Republic is a sovereign, unitary and democratic, law-abiding State, based on respect for the rights and freedoms of man and citizen" (art. 1(1)). The constitutional state allows, however, also for decentralization at the local and regional levels. The 1992 Czech Constitution states in Chapter 1 on "Basic Provisions" that "[t]he autonomy of units of territorial self-administration shall be guaranteed" (art. 8), while Chapter 7 on "Territorial Self-Administration" stipulates the decentralized, "basic units of territorial self-administration" as municipalities, and higher units in the form of lands and regions (art. 99). Article 100 states that "communities of citizens, inhabiting a particular area ... have the right of self-government", while article 101(3) underlines local autonomy in that "[s]elf-governing territorial divisions are public-law corporations which may have their own property and which operate according to their own budget". 
While the value of subnational self-government and civil society, and related institutions, are entrenched in the constitution, significant (political as well as social) obstacles to the realization of principles of local self-government seem not have been overcome in two decades of transformation, and the centralistic nature of the Czech state can only partially be said 'corrected' by local and regional autonomy. However, at the same time, it would be hard to deny the continuing importance of decentralization and ideas of self-governance for democratization in the Czech Republic.

Throughout the 1990s, the latter was particularly visible in the form of a conflictive debate between Václav Havel (and the Czech left) and Václav Klaus (and the Civic Democratic Party or Občanská demokratická strana (ODS)) on the role and form of especially the regional level of government. Klaus opposed issues of reform and decentralization on grounds of neoliberal skepticism towards bureaucracy and intermediary institutions, and held off the implementation of article 99 of the Constitution. Eventually, though, at the end of the 1990s, significant decentralizing steps and the creation of a regional layer were effected, not least due to EU pressure (cf. Calda 1999). The constitutional act of 3 December 1997 on the "Creation of Higher Territorial Self-Governing Units" changed article 99 into "[t]he Czech Republic is subdivided into municipalities, which are the basic territorial self-governing units, and into regions, which are the higher territorial selfgoverning units". And indeed, there are indications that the regional level has grown in importance since its establishment. Recently, Baun and Marek have argued that the "new regions have begun establishing themselves as legitimate and important political actors" (425).

The constitutional status of subnational self-government was further entrenched by a number of rulings by the Czech Constitutional Court. For instance, in 2003 the Constitutional Court ruled that

The guarantee of territorial self-government in the Constitution is laconic. Alongside the differentiation of the local and regional levels of self-government (Art. 99) territorial self-government is conceived as the right of a territorial association of citizens, arising from its characteristics and abilities, as the Constitutional Court stated in its finding of 19 November 1996, file no. Pl. ÚS 1/96 (Collection of Decisions of the Constitutional Court, volume 6, p. 375).

The Constitutional Court considers local self-government to be an irreplaceable component in the development of democracy. Local self-government is an expression of the capability of 
local bodies, within the bounds provided by law, to regulate and govern part of public affairs on their own responsibility and in the interest of the local population. (CC 2003/02/05 - Pl. ÚS 34/02: Territorial Self-Government; emphasis added)

Later in 2003, the constitutional court further underlined the importance of fiscal autonomy of regions and municipalities:

According to the starting thesis, on which the concept of selfgovernment is built, the foundation of a free state is a free municipality, then, in terms of regional significance, at a higher level of the territorial hierarchy a self-governing society of citizens, which, under the Constitution, is a region. With this concept of public administration built from the ground up, the following postulate must be immanent to self-government, as an important element of a democratic state governed on the rule of law: that a TSU must have a realistic possibility to handle matters and issues of local significance, including those which by their nature exceed the regional framework and which it handles in its independent jurisdiction, on the basis of free discretion, where the will of the people is exercised at the local and regional level in the form of representative democracy and only limited in its specific expression by answerability to the voter and on the basis of a statutory and constitutional framework (Art. 101 par. 4 of the Constitution). Thus, territorial self-governing units representing the territorial society of citizens must have - through autonomous decision-making by their representative bodies - the ability to freely choose how they will manage the financial resources available to them for performing the work of self-government. It is this management of one's own property independently, on one's own account and own responsibility which is the attribute of self-government. Thus, a necessary prerequisite for effective performance of the functions of territorial self-government is the existence of its own, and adequate, financial or property resources. (2003/07/09 - Pl. ÚSD 5/03: Territorial Self-Government Unit) 


\section{Constitutional Design of Local Democracy}

As mentioned earlier, the Czech constitution defines Czech democracy in a predominantly representative, parliamentary manner. This is, however, paralleled by constitutional foundations of subnational representative democracy as well as more direct forms of civic participation.

It should be noted that the 1992 Constitution was predominantly designed by a government commission dominated by the ODS, which squarely favored a centralistic state without intermediary levels. The articles on local self-government that were ultimately included in the 1992 document were the result of a compromise between the ODS, its coalition members (more favorable to local government), and the opposition. The compromise led to a fairly vague and open-ended formulation, and, as noted above, the regional level was not implemented before 1999, but the Czech Constitution does go some way in qualifying a fully centralistic as well as liberal-representative view of the Czech state.

The Constitution arranges for representative democracy on the subnational level in article 101, which states that both municipalities and regions are administered by councils, which are "elected by secret ballot on the basis of universal, equal, and direct suffrage" (art. 102). The political status of subnational democracy is enhanced by the fact that, even if the turn-out rates for both the elections of regional and municipal councils are generally not very high, in particular the municipal institutions enjoy a very high level of political trust among the Czech citizens, much more so than those on the national level (Illner 2010: 519).

Symbolic-substantive references to subnational democracy can be further found in the Czech Bill of Rights - the "Charter of Fundamental Rights and Basic Freedoms" - which can be considered part of the constitutional constellation. The Charter invokes the Czech "nations' traditions of democracy and self-government", and also refers to the fact that "[c]itizens have the right to participate in the administration of public affairs either directly or through the free election of their representatives" (art. 21(1)) (emphasis added).

Turning to forms of direct democracy, the institutionalization of civic participation is rather weak in the Czech Republic. Thus, in a fairly stark contrast to the intensity of republican ideas of Charter 77 of the 1980s (see Renwick 2006; Blokker 2011), post-1989 Czech democracy appears to display the least extensive form of constitutional and legal institutionalization of forms of direct democracy - at least regarding the instrument of civic consultation through referenda - in the region. To be sure, elements of direct democracy are not prominent in the Czech Constitution. And while, as a 
result of a compromise, the 1992 constitution does entail the formulation that "[a] constitutional law may stipulate the cases when the people exercise state power directly" (art. 2(2); emphasis added), to date no such law has been adopted, despite repeated attempts by pro-referendum groups (see for an extensive overview of such attempts, Adamova 2010).

But at closer look, while it is clear that political forces skeptical of referenda and direct democracy have so far prevailed, the issue is clearly not settled yet and continues to re-emerge in Czech political debate. For instance, in 2002, in the context of debates over the referendum on EU accession, a constitutional act for a general, national right to referendum was proposed, but was (once again) rejected by right-wing parties. Ultimately, an act on referendum was adopted that related only to EU membership.

But while a constitutionally guaranteed right to the holding of national referenda is still absent, referenda on the local level have become much more consequential (on the regional level, referenda are not permitted). Admittedly, during the 1990s referenda were only used for questions of secession from existing municipal arrangements. And while the original legislation regarding local government - the 1992 Law on Local Elections and Referendums notably stems from the Civic Forum period, no referendum of general import took place on its basis in the first decade of democratization. However, following the amendments of the law in 2004 and 2008, clearing a number of ambiguities and strengthening the position of referenda proposers, local referenda have become a much more significant - and binding - civic instrument in Czech democracy, and are used for much wider purposes than before (see Smith 2011; Adamova 2010: 53-4).

\section{HUNGARY}

The Hungarian democratic state can be defined a "decentralized unitary" one - "[t]he Republic of Hungary is an independent, democratic constitutional state" (art. 2(1)) - with a "strong and decentralized system of county governments" (Soos-Kakai 2010: 530). Local government is strongly entrenched in the Hungarian case, and enjoys a high level of autonomy in decision-making. Local democracy is mostly focused on representative, party-based democracy, while civic input and NGO participation are so far limited.

Below, I will describe the constitutional contours of both local selfgovernment and local democracy as it has emerged in Hungary between 1990 and 2010. It will become clear that Hungary arguably has one of the strongest local government systems in the region, but equally that the democratic 
potential of such a system is not used to the fullest extent. What is more, current constitutional turmoil might seriously undermine past achievements.

\section{Constitutional Design of Local Government}

In the constitutional changes of the early 1990s, local self-government enjoyed a high priority in that it was seen as an indispensable way of undermining the centralist institutions of "democratic centralism". Thus, "the replacement of the council-based public administrative system with a sphere of independent local self-government was a key concern in administrative reform" (Balázs 1993: 76). The amended Constitution of 1949 dedicates chapter IX to Local Governments, in which article 42 on the "Right to local government" now states: "Eligible voters of the communities, cities, the capital and its districts, and the counties have the right to local government. Local government refers to independent, democratic management of local affairs and the exercise of local public authority in the interests of the local population". The main sub-national distinction is between the local level (villages, cities, capital districts, capital) and the county level. A regional level was added in 2000 to be able to attract EU Structural Funds, but its status so far is weak (Soós 2010: 113-14). In contrast, local governments of the municipal type, and to a lesser extent counties, are the entities with most political significance on the subnational level.

Democratic reforms towards decentralization involved mainly two stages. In 1990, the parliamentary Act No. LXV on Local Governments was adopted, which "established the legal foundation for the process of democratization and reform of the political system". The Act LXV is introduced as follows:

Following the progressive local government traditions of our country, as well as the basic requirements of the European Charter on local governments, Parliament recognizes and protects the rights of the local communities to self-government. Local selfgovernment makes it possible, that the local community of electors - directly, and/or through its selected local government - manage the public affairs of local interest independently and democratically. Supporting the self-organizing independence of local communities, Parliament assists the creation of the conditions necessary to self-government, it promotes the democratic decentralization of public authority (Act No. LXV).

Moreover, the Act No. LXIV on Local Elections was adopted, arranging for 
local democracy to start functioning. In a second stage, in 1994, the existing local system was reformed by means of the Act on Local Governments (No. LXIII). These reforms included a call for broader constitutional guarantees of local government, steps towards more direct participation (the direct election of mayors), and the regulation of civic participation and publicity.

These reforms have led some observers into saying that "[w]ithout doubt, the 1990 local government reform established one of the most liberal systems of local government in Europe" (Balazs 1993: 85). Also others have argued that in 1990 legislation was adopted that established a "very high degree of autonomy for the lowest, local level of government", while the constitution enshrined the right to self-government at local and county levels as a constitutional principle (Fowler 2001: 8).

But while it has been acknowledged that this "rapid institutional reform was unique" (Fowler 2001), it needs at the same time to be recognized that the extensive nature of the reforms have led to a relatively high level of fragmentation and dysfunctionality of local democracy and government. In this, the counterreaction to the hypercentralization of the communist regime has not necessarily led to adequate decentralized structures. That said, the significance of an institutional dimension of local government in Hungary even if in need of amelioration - seems evident enough.

\section{Constitutional Design of Local Democracy}

Local democracy as a citizens' right - in both indirect and direct ways - is entrenched in the Hungarian constitutional order, in that article 44 (1) stipulates that " $[\mathrm{e}]$ ligible voters exercise the right to local government through the representative body that they elect and by way of local referendum". ${ }^{4}$ In Act no. LXV, a similar idea is expressed in art. 1(4) as "[t]he local government may - through the elected local body of representatives, or with the decision of local plebiscite - undertake independently and voluntarily the solution of any local public affair, which is not referred by a legal rule to the jurisdiction of another organ". And also in the Hungarian case, it can be argued that local democracy enjoys a relatively high standing in terms of

4 In the new constitution, unilaterally adopted by Fidesz in April 2011, the representative dimension of local democracy is clearly articulated: "[ $t$ ]he members of the local representative body and the mayors are elected by the citizens on the basis of universal and equal suffrage, with direct and secret ballot, at elections articulating the free will of the people in a manner defined by super majority law" (art. 35(1)). The instrument of local referendum is mentioned once in the draft text, but not in the section on local government, and without further stipulation. 
civic political trust. Local governments (with the institutions of the president and the constitutional court) tend to score significantly higher than both the parliament and the government (Soós and Kákai 2010: 541).

Institutions of direct democracy on the local level are fairly well-entrenched in the Hungarian case. In general, "demands for referendums were part of the movement for democracy" and since the transition, "no political party has denied that at least certain forms of direct democracy should be part of the Hungarian constitutional and political order", Dezső and Bragyova 2001: 63). In the late 1980s, the reaction of the Communist party to the opposition's demand for referenda resulted in Act XVII, adopted unilaterally in June 1989. This legal act was the basis for referenda and popular initiatives until 1997, when it was renewed and partially replaced by constitutional articles. The earlier act - according to András Sajó a "very poorly drafted document" (2006) - was widely contested because of various lacuna, not least in procedural terms. What is more, there was a strong suspicion of its unconstitutionality.

In 1997, a new set of rules was constitutionalized through a constitutional amendment (Act C of 1997 on Electoral Procedure), and can be regarded as at least partially the outcome of initiatives related to the democratization movement of the 1980s. Even if the "scope and conditions of referenda were gradually restricted since 1989", the amendment of the constitution enhanced the status of direct democracy considerably (i.e. Chapter XV on local referendums and Chapter XVI on local initiative). The constitutional status of referenda was reiterated by a ruling of the Constitutional Court in which it argued that the "institution of referendum is closely related to the provisions of the Constitution. Referendum, as typical form of direct democracy, is related to the sovereignty of the people, and, the practice of the Court interprets the right to referendum as political fundamental right" (website Hungarian Constitutional Court; decision 52/1997; emphasis added).

While in general the Hungarian democratic system is a representative one, the constitutionalization of instruments of direct democracy has created a tension between direct democracy and the predominantly liberal, representative idea as constitutional principles. To some extent, "direct democratic institutions already have a foothold in Hungarian constitutional thought" (Dezsö and Bragyova 2007: 82 , even if the institutions are still not sufficiently well-defined. ${ }^{5}$

5 Schiller classifies Hungary's procedures of local direct democracy as of 'medium' quality, together with the Czech Republic and a majority of the German states (Schiller 2011: 19). Schiller further argues that in a comparative context, Hungary, at least in contrast to Belgium, Luxemburg, and Spain, displays "substantial rates of activity" of local direct democracy (2011: 22). 


\section{POLAND}

Also the Polish constitutional state is defined as a unitary and centralized state, even if allowing for subnational government on the regional and local levels. In other words, while, as expressed in article 3 of the 1997 Constitution, Poland has without a doubt a unitary system, its constitutional order allows for "relatively strong local autonomy" and tendencies towards strengthening regionalization are visible (Swianiewicz 2010: 482). The latter becomes already clear from the preamble - “... [h] ereby establish this Constitution of the Republic of Poland as the basic law for the State, based on respect for freedom and justice, cooperation between the public powers, social dialogue as well as on the principle of aiding in the strengthening the powers of citizens and their communities" (emphasis added).

Below, I will briefly describe the constitutional contours of both local selfgovernment and local democracy as it has emerged in particular in the Polish Constitution of 1997, as well as in the process of regionalization of the last few years of the 1990s.

\section{Constitutional Design of Local Government}

In the Polish case, local self-government was a prominent focus in the constitution-making process, and has been amply arranged for in the 1997 Constitution. The process of decentralization already started in the early 1990s, and had in many ways been prepared by the political struggle of the Solidarność trade union for decentralized government (cf. Benzler 1994; also Blokker 2011). The Local Government Act of 1990 provided the fundamental legal underpinnings of the right to self-governance of local authorities. In addition, almost all of Solidarność's demands for territorial self-government were enshrined in the articles 43-47 of the amended 1952 constitution, while these were later re-confirmed in the so-called Small Constitution of 1992.

The 1997 constitution has often been criticized of being rather unspecific with regard to notions of local self-government and decentralization, but it can at the same time be argued that the dimension of local self-government is strongly anchored in the text. As noted above, the symbolic-substantive dimension of self-government and subsidiarity is reflected in the preamble, indicating their status as foundational-constitutional values. The constitutional text itself introduces local self-government as early as article 15 - "[t]he territorial system of the Republic of Poland shall ensure the decentralization of public power" (1) - and 16 -"[t]he inhabitants of the units of basic territorial 
division shall form a self-governing community in accordance with law"(1) - and "[1]ocal self-government shall participate in the exercise of public power. The substantial part of public duties which local self-government is empowered to discharge by statute shall be done in its own name and under its own responsibility" (2). The constitution arranges for local self-government in a detailed way in chapter VII. It should be noted (cf. Swianiewicz 2010: 484), however, that only the local, municipal level (gmina) is arranged for in the constitution (art. 164(1)), while the other, regional and county, levels are to be arranged for by statute (164(2)). In substantive-symbolic terms therefore, local self-governance at the municipal level is prioritized.

The process of decentralization and the creation of local self-government has arguably been a success in Poland, and is one of the most effective even if continuously contested - reforms in the region (contestation regards in particular the status of the subnational levels other than that of municipalities). The attention for local self-government and civic participation can be clearly related to the dissident legacy of Solidarność, even if the latter's original idea of a "self-governing republic" has never been realized in any extensive way. On the one hand, it can then be argued that "local self-government in Poland found a permanent place within the post-transformation political landscape", not least through its constitutionalization, but at the same time, it can be said that there are clear tendencies at recentralization and state disregard for local autonomy (Regulska 2009). What is significant, though, is that tensions and contestations over the desirable form of local self-government, and appropriate relations between the centre and periphery continue to exist, indicating the unsettled nature of local democracy and the continuous relevance and discursive force of the notion of self-government.

\section{Constitutional Design of Local Democracy}

Local government is underpinned by both representative and direct forms of democracy in Poland: "[e]lections to constitutive organs shall be universal, direct, equal and shall be conducted by secret ballot. The principles and procedures for submitting candidates and for the conduct of elections, as well as the requirements for the validity of elections, shall be specified by statute "(169(2)), and "[m]embers of a self-governing community may decide, by means of a referendum, matters concerning their community, including the dismissal of an organ of local government established by direct election. The principles of and procedures for conducting a local referendum shall be specified by statute" (170). Local elections are arranged for by the 1998 
Local Election Law. Also in the Polish case, turnout for local elections tends to be relatively low (it has never been higher than 50 percent since 1990, see Swianiewicz 2010: 497), but public opinion polls show consistently higher civic trust towards local institutions than towards central political institutions.

In terms of direct democracy as a dimension of post-1989 Polish local democracy, it is clear that it has become a "common element of democratic decision-making” (Přibáň \& Sadurski 2006: 218; cf. Piasecki 2011: 136). Dimensions of participatory democracy - in particular through the form of referenda - have taken on a certain significance in the Polish democratic architecture in their own right, and already from the late 1980s onwards (see Piasecki 2011).

The institutionalization of instruments of direct democracy started early on in the Polish transformation. Two constitutional amendments in late 1989 and early 1990 introduced a change of the 1952 constitution so that sovereignty was now vested in the nation, and could be exercised in a representative as well as a direct way. The Local Government Act of 1990 included the option of popular vote, next to that of regular elections, and identified three types of referenda: mandatory (recall), mandatory (self-taxation), and facultative (matters of importance to the commune (Piasecki 2011: 126-7). The Local Referendum Act of 1991 further stipulated the implementation of referenda.

Instruments of direct democracy were also articulated forcefully in most constitutional drafts proposed throughout the early 1990s, and in the newly adopted Constitution in 1997 even gained somewhat in importance. The Polish constitution invokes a notion of direct civic participation as early as in article 4(2), and the strengthening of citizens power is alluded to in the preamble. The 1997 constitution codifies the citizens' right to direct participation through referenda in constitutional matters, national referenda regarding ordinary legislation, and referenda on the local level. Article 170 stipulates that "[m]embers of a self-governing community may decide, by means of a referendum, matters concerning their community, including the dismissal of an organ of local self-government established by direct election. The principles of and procedures for conducting a local referendum shall be specified by statute".

It seems fair to argue that the 1997 Constitution, "unlike all its predecessors, contains a relatively wide range of provisions concerning direct democracy", which is a "fact worth stressing, especially as such solutions are rare in Polish history" (Szmyt 1999: 128-129). This interpretation is confirmed by the legal scholar Ewa Popławska, who has argued that the "increasing value of direct democracy is reflected in its extended forms, in particular in the extension 
of the scope of facultative application of a referendum to include matters of fundamental importance to the state" (Popławska 1999: 189). As for instance argued by a current judge of the Constitutional Court, Stanisław Biernat, the referendum instrument does have particular significance on the local level (Biernat 2005). This observation is corroborated by the sociologist Pawel Swianiewicz, who in the early 2000s observed some positive trends in terms of more frequent and widespread use of local referenda, and a higher success rate (Swianiewicz 2001).

\section{CONCLUSIONS}

Following, among others, Bailey and Elliott, I have argued that a "virtuous circle" of subnational government and democracy mutually enforcing each other is only likely to come about in a constitutional context of sufficiently decentralized and autonomized local self-government with a variety of democratic channels, and the unambiguous endorsement of constitutionalized subnational self-government by relevant political and legal actors. The concise review of the relevant foundational legal structures as have been adopted in the cases of the Czech Republic, Hungary, and Poland since 1989 shows that, on the one hand, significant steps towards subnational self-government have clearly been made, but also that, on the other, subnational equilibria and state-local relations are in some instances fragile, and do not always enjoy sufficient legal guarantees or the protection of clear-cut constitutional principles. Furthermore, distinct problems with decentralization ${ }^{6}$ await further steps of reform.

In the Czech Republic, both the local and the regional level are part of the constitutional make-up. The 1992 Constitution indicates both levels as basic and higher units of territorial government respectively. The regional level was, however, only implemented in the later 1990s, after protracted political conflict over its necessity, and following sharp critique by the EU on the lack of an adequate regional administrative structure. The belated implementation of the regional level has, according to some observers, resulted in a lower level of civic trust in regional institutions and less political prominence. This is exacerbated by a limited autonomy in financial matters as well as the

6 These include far-going municipal fragmentation in the Czech Republic and Hungary; the clarification of relations between the various subnational levels and the centre, as well as organizational clarity regarding prerogatives and duties; the predominance of national political parties on the local level; and limited civic participation. 
continued existence of regional structures directly administered by the state (Illner 2010: 522-3). Regarding local and regional democracy, democratic institutions and mechanisms are clearly available on the subnational level. The local level is, however, the only level on which direct democracy is provided for in terms of referenda, an instrument that is increasingly put to use (Smith 2011).

In Hungary ${ }^{7}$, the constitution identifies various levels of subnational selfgovernment, but the local, municipal (and county) levels are clearly the ones that are more significant, not least because of the stipulation of a relatively wide set of responsibilities and a relatively high level in the independence of finance (Soos-Kákai 2010: 532). Also in Hungary, local, municipal-level selfgovernment has enjoyed priority throughout the transformation period. As Soós has argued, '[1]egally speaking, the rights of local governments are well protected' (2010: 125). The middle-tier (including that of counties) has, in this, become somewhat more important only later on. In terms of local democracy, representative mechanisms are well-established while direct forms (referenda as well as a citizens' initiative) have only been constitutionally enshrined in 1997, while referenda have been endorsed by the Constitutional Court as a "fundamental political right". Despite such legal safeguards, however, local democratic politics is - according to some observers - not of high quality, even if participation through elections is increasing (Soós-Kákai 2010: 549).

In Poland, the constitution prioritizes both subnational government and democracy on the local, municipal level. Only the latter has constitutional status (as the "basic unit of local government"), although its status is subject to political conflict and attempts at recentralization by the central state (Regulska 2009). Since 1998, county and regional levels have been added to the subnational picture, but regional self-government is paralleled by regional decentralized state institutions. Despite their limited functions and financial autonomy, regions do seem to have created a "new political dynamism" and are slowly becoming more robust, according to some observers (Swianiewicz 2010: 501).

The aforementioned political conflict over decentralization tends to undermine subnational forms of democracy in Poland (cf. Regulska 2009). Such conflict negatively influences the potential of local self-government, but also that of local democracy and civic participation. While local democracy is well-entrenched in both its representative and direct (local referenda) forms, the parameters for local autonomy seem not always unambiguously respected by the central state institutions, political parties, as well as local elites, and

7 The full impact of current constitutional turmoil on subnational self-government will unfortunately have to await the evolvement of events. 
a functional, rather than a democratic-participatory interpretation of local self-government seems to prevail so far (Swianiewicz 2010: 484). At the same time, civil society institutions are mostly not strong enough to provide sufficient counterthrust.

\section{ACKNOWLEDGEMENT}

The author acknowledges a post-doctoral fellowship of the Provincia Autonoma di Trento, held at the department of Sociology and Social Research, University of Trento, Italy.

\section{REFERENCES}

\section{Legal Documents}

Act No. LXV on Local Governments, 1990, Hungary.

Act No. LXIII on Local Governments, 1994, Hungary.

Act C of 1997 on Electoral Procedure, Hungary.

Charter of Fundamental Rights and Basic Freedoms, 1992, the Czech Republic.

Constitution of the Czech Republic, 1992.

Constitution of Hungary, 2003.

Constitution of Poland, 1997.

Draft Constitution Hungary, 2011.

European Charter of Local Self-Government, Council of Europe, 1985.

Law on Local Elections and Referendums, 1992, the Czech Republic.

Local Government Act, 1991, Poland.

Local Referendum Act, 1991, Poland.

\section{Secondary literature}

Adamova, K. (2010), 'Referendum in the second half of the $20^{\text {th }}$ and at the beginning of the $21^{\text {st }}$ centuries: its potential and limits', in: M. Tomasek et al. (eds), Czech Law. Between Europeanization and Globalization, Prague: Karolinum Press, pp. 48-53.

Bailley, S. and M. Elliott (2009), 'Taking Local Government Seriously: Democracy, Autonomy and the Constitution', The Cambridge Law Journal, 68. pp. 436-472.

Balázs, I. (1993), "The Transformation of Hungarian Public Administration", Public Administration, 71 (1993), pp. 75-88.

Baun, M. and D. Marek (2006), 'Regional Policy and Decentralization in the Czech 
Republic', in: Regional and Federal Studies, Vol. 16, No. 4, pp. 409-428.

Benzler, S. (1994), "Transformation der Dauerzustand? Die Entwicklung der territorialen Selbstverwaltung in Polen", in: U. Bullmann (ed), Die Politiek der dritten Ebene. Regionen im Europe der Union (Baden-Baden: Nomos), pp. 310339.

Biernat, S. (2005), "Demokratieprinzip im polnischen Verfassungssystem", in: H. Bauer, P.M. Huber, K.-P. Sommermann (eds.), Demokratie in Europa (Tübingen: Mohr Siebeck), pp. 79-106.

Blokker, P. (2010), 'Democratic Ethics, Constitutional Dimensions, and Constitutionalisms', in: A. Febbrajo \& W. Sadurski (eds.), East-Central Europe After Transition: Towards a New Socio-legal Semantics, Ashgate.

Blokker, P (2011), 'Dissidence, Republicanism, and Democratic Change', in: East European Politics and Societies 15:2, pp. 219-243.

Bryson, P.J. (2008), " "State administration” vs. self-government in the Slovak and Czech Republics', in Communist and Post-Communist Studies, 41, pp. 339-358.

Calda, Milos (1999), 'Constitution-Making in Post-Communist Countries: A Case of the Czech Republic', paper presented at a panel of the Center for the Study of the Constitution at the American Political Science Association Convention, Atlanta, Georgia, September 2/5, 1999.

Dezső, M. and A. Bragyova (2001), "Hungary", in: A. Auer and M. Buetzer (eds), Direct Democracy: The Eastern and Central European Experience (Ashgate), pp. 63-93.

Dezső, M. and A. Bragyova (2007), "National Referendums in Hungary”, in: A. Jakab, P. Takacs, A.F. Tatham (eds), The Transformation Of The Hungarian Legal Order 1985-2005 - Transition to the Rule of Law and Accession to the European Union (Kluwer Law International), pp. 68-82.

Fowler, B. (2001), "Debating Sub-state Reform on Hungary's 'Road to Europe' “, Working 21/01, CREES (2001).

Illner, M. (2010), 'The Czech Republic: Local Government in the Years After the Reform', in: J. Loughlin, F. Hendriks and A. Lidstrom (2010), The Oxford Handbook of Local and Regional Democracy in Europe, Oxford University Press, pp. 505-527.

Loughlin, J., F. Hendriks and A. Lidstrom (2010), The Oxford Handbook of Local and Regional Democracy in Europe, Oxford University Press.

Mill, J.S. (2004), Representative Government.

Piasecki, A.K. (2011), 'Twenty Years of Polish direct democracy at the local level' in: Schiller, T. (2011), Local Direct Democracy in Europe, Wiesbaden: VS Verlag, pp. 126-137.

Přibán̆, J. and W. Sadurski, "The Role of Political Rights in the Democratization of Central and Eastern Europe", in: W. Sadurski (ed.), Political Rights under Stress in 21st Century Europe (Oxford: Oxford University Press, 2006): 196-238.

Popławska, E. (2002), "The New Constitutional Principle of Subsidiarity and 'the Diminishing State' in Poland", in: Journal of Constitutional law in Eastern and Central Europe 9(1), pp. 51-95. 
Popławska, E. (1999), "The Principle of Representative Government and Forms of Direct Democracy and Their Application in Polish Constitutional Law", in: M. Wyrzykowski (ed.), Constitutional Essays (Warsaw: Institute of Public Affairs), pp. 155-189.

Regulska, J. (2009), "Governance or Self-governance in Poland? Benefits and Threats 20 Years Later", International Journal of Politics, Culture \& Society 22(4),pp. 537-556.

Renwick, A. (2006), “Anti-Political or Just Anti-Communist? Varieties of Dissidence in East-Central Europe and Their Implications for the Development of Political Society", East European Politics and Societies 20:2 (2006), pp. 286-318.

Sajó, A. (2006), "The Republic of Hungary”, in: C. A. J. M. Kortmann, J. W. A. Fleuren, Wim Voermans, Miluše Kindlová (eds), Constitutional law of $10 \mathrm{EU}$ member states: the 2004 enlargement (Kluwer, 2006): IV-3 - 55, IV-15.

Schiller, T. (2011), 'Local Direct Democracy in Europe - a comparative overview, in: Schiller, T. (2011), Local Direct Democracy in Europe, Wiesbaden: VS Verlag, pp. 9-32.

Schiller, T. (2011), Local Direct Democracy in Europe, Wiesbaden: VS Verlag.

Skapska, G. (2011), From 'Civil Society' to 'Europe'. A Sociological Study on Constitutionalism after Communism, Leiden: Brill.

Smith, M. (2011), 'The uneasy balance between participation and representation: local direct democracy in the Czech republic', in: Schiller, T. (2011), Local Direct Democracy in Europe, Wiesbaden: VS Verlag, pp. 33-53.

Soós, G. (2010), Hungary', in: M.J. Goldsmith and E.C. Page (eds), Changing Government Relations in Europe. From localism to intergovernmentalism, Routledge, pp. 108-126.

Soós, G. and L. Kákai (2010), 'Hungary: Remarkable Successes and Costly Failures: An Evaluation of Subnational Democracy', in: J. Loughlin, F. Hendriks and A. Lidstrom (2010), The Oxford Handbook of Local and Regional Democracy in Europe, Oxford University Press, pp. 528-551.

Swianiewicz, P. (2001), "Sympathetic Disengagement: Public Perception of Local Governments in Poland", in: P. Swianiewicz (ed.), Public Perception of Local Governments (Budapest: Local Government and Public Reform Initiative): 208211.

Swianiewicz, P. (2010), 'Poland: Europeanization of Subnational Governments', in: J. Loughlin, F. Hendriks and A. Lidstrom (2010), The Oxford Handbook of Local and Regional Democracy in Europe, Oxford University Press, pp. 480-504.

Szmyt, A. (1999), "Representation - Elections - Democracy", in: P. Szarnecki, A. Szmyt, Z. Witkowski (eds), The Principles of Basic Institutions of the System of Government in Poland (Warsaw: Sejm Publishing Office), pp. 119-134. 